\title{
Platelet-derived Growth Factor and Fibroblast Growth Factor Differentially Regulate Interleukin $1 \beta-$ and cAMP-induced Nitric Oxide Synthase Expression in Rat Renal Mesangial Cells
}

\author{
Dieter Kunz, ${ }^{\star}$ Gaby Walker, ${ }^{\star}$ Wolfgang Eberhardt, ${ }^{\circ}$ Udo K. Messmer, ${ }^{\ddagger}$ Andrea Huwiler, ${ }^{\S}$ and Josef Pfeilschifter ${ }^{\ddagger}$ \\ *Department of Pharmacology, Biozentrum, University of Basel, CH-4056 Basel, Switzerland; ${ }^{\ddagger}$ Zentrum der Pharmakologie, Klinikum \\ der Johann Wolfgang Goethe-Universität, D-60590 Frankfurt am Main, Germany; and ${ }^{\S}$ Center for Biomembranes and Lipid \\ Enzymology, University of Utrecht, NL-3584 CH Utrecht, The Netherlands
}

\begin{abstract}
Platelet-derived growth factor (PDGF) and basic fibroblast growth factor (bFGF) regulate mesangial cell proliferation and matrix production in vitro and in vivo and crucially participate in the pathogenesis of glomerulonephritis. We investigated whether PDGF-BB and bFGF influence nitric oxide (NO) production, another important effector molecule in inflammatory glomerular injury.

Inducible NO synthase (iNOS) induction in rat glomerular mesangial cells has been described in response to two principal classes of activating signals comprising inflammatory cytokines such as interleukin $1 \beta$ (IL-1 $\beta$ ) or elevation of cyclic AMP (cAMP). Treatment of mesangial cells with IL-1 $\beta$ induces iNOS activity measured as nitrite levels in cell culture supernatants. Coincubation of mesangial cells with PDGF-BB inhibits production of nitrite by $\sim 95 \%$. This effect can be reversed by the simultaneous incubation of PDGF-BB in the presence of calphostin C, a potent and selective inhibitor of protein kinase $C$. In contrast, incubation of cells in the presence of bFGF potentiates IL-1 $\beta$-induced production of NO and is functionally associated with an increased rate of apoptosis of mesangial cells. Western blot analyses reveal that PDGF-BB causes a decrease in the formation of iNOS protein which is preceded by decreases in iNOS mRNA steady state levels. bFGF drastically increases iNOS protein levels as well as the corresponding iNOS mRNA steady state levels. Nuclear run-on experiments reveal that PDGF-BB decreases the IL-1 $\beta$-induced transcription rate of the iNOS gene, whereas bFGF potentiates the transcriptional activity of the iNOS gene. Northern blot analyses demonstrate that bFGF strongly potentiates the formation of IL-1 $\beta$-induced IL-1 type I receptor mRNA levels, whereas PDGF-BB has no effect.

Treatment of mesangial cells with the membrane-permeable cAMP analogue $N^{6}, O-2^{\prime}$-dibutyryladenosine $3^{\prime}, 5^{\prime}$-phos-
\end{abstract}

Dieter Kunz and Gaby Walker contributed equally to this study.

Address correspondence to Prof. Josef Pfeilschifter, Zentrum der Pharmakologie, Klinikum der Johann Wolfgang Goethe-Universität, Theodor-Stern-Kai 7, D-60590 Frankfurt am Main, Germany. Phone: 49-69-6301-6951; FAX: 49-69-6301-7942; E-mail: Pfeilschifter@em.unifrankfurt.de

Received for publication 14 March 1997 and accepted in revised form 14 October 1997.

J. Clin. Invest.

(C) The American Society for Clinical Investigation, Inc. 0021-9738/97/12/2800/10 \$2.00

Volume 100, Number 11, December 1997, 2800-2809

http://www.jci.org phate $\left(\mathrm{Bt}_{2} \mathrm{cAMP}\right)$ markedly increases the production of nitrite. Whereas PDGF-BB does not affect cAMP-induced nitrite levels, bFGF strongly potentiates them. PDGF-BB alters neither cAMP-induced iNOS protein levels nor the corresponding iNOS mRNA steady state levels. By contrast, bFGF superinduces cAMP-stimulated iNOS protein and iNOS mRNA levels. These changes by bFGF are due to an increase in cAMP-induced transcriptional activity of the iNOS gene which is not affected by PDGF-BB.

In summary, the results show that PDGF and bFGF differentially regulate iNOS expression in mesangial cells in a stimulus-specific way. The timely sequence of expression of PDGF and bFGF and of cytokines like IL-1 will crucially determine the amounts of NO produced and the functional consequences thereof in the course of progressive glomerular diseases. (J. Clin. Invest. 1997. 100:2800-2809.) Key words: nitric oxide $\bullet$ growth factors $\bullet$ rat mesangial cells $\bullet$ apoptosis $\bullet$ protein kinase $\mathrm{C}$

\section{Introduction}

Nitric oxide (NO) ${ }^{1}$ is a free radical gas mediating intercellular communications in many mammalian organs. In recent years the importance of NO for the regulation of vascular homeostasis, the involvement in neurotransmission, and the defense against infectious agents has become established $(1,2)$. Three isoforms of NO synthase (NOS) have been identified and cloned $(3,4)$. The neuronal and endothelial enzymes are constitutively expressed and their enzymatic activity is regulated by changes in concentration of intracellular free $\mathrm{Ca}^{2+}$. The third member of the family of NOSs is the inducible NOS (iNOS). This enzyme is regulated at the transcriptional level and the activity is independent of changes in intracellular free $\mathrm{Ca}^{2+}$. iNOS is expressed in many different cell types and produces high levels of NO. Excessive formation of NO mediates the bactericidal and tumoricidal actions of macrophages. However, under pathological conditions, high output of NO is associated with tissue damage observed in arthritis, insulitis, septic shock, and nephritis (for reviews see references 1 and 2).

The importance of the L-arginine/NO pathway for the pathogenesis of certain forms of glomerulonephritis is documented in the literature (for reviews see references 5 and 6). Cattell and co-workers (7-10) demonstrated ex vivo production of nitrite in glomeruli isolated from rats with four differ-

1. Abbreviations used in this paper: bFGF, basic fibroblast growth factor; $\mathrm{Bt}_{2} \mathrm{cAMP}, N^{6}, O-2^{\prime}$-dibutyryladenosine $3^{\prime}, 5^{\prime}$-phosphate; iNOS, inducible isoform of nitric oxide synthase; L-NMMA, L- $N^{\mathrm{G}}$-monomethyl-L-arginine; NO, nitric oxide; NOS, nitric oxide synthase; PDGF-BB, BB isoform of PDGF; PKC, protein kinase C. 
ent models of immune complex-mediated glomerular injury, including Thy 1.1 glomerulonephritis. Weinberg and colleagues (11) reported that oral administration of an iNOS inhibitor, L- $N^{\mathrm{G}}$-monomethyl-L-arginine (L-NMMA), a structural analogue of L-arginine, prevents the development of glomerulonephritis in MRL-lpr/lpr mice that develop a spontaneous autoimmune disease. Narita et al. (12) have shown that in antithymocyte serum-induced glomerulonephritis complement-dependent mesangial cell lysis can be prevented by pretreatment of the rats with L-NMMA, suggesting that glomerular injury in this model is NO mediated.

Mesangial cells are a major determinant in the regulation of glomerular filtration rate $(13,14)$. In coincubation experiments it was demonstrated that NO released from glomerular endothelial cells increases cGMP in mesangial cells, thus inhibiting angiotensin II-induced mesangial cell contraction (15). Moreover, mesangial cells are not only a target for NO, but have themselves the capacity to produce NO (for reviews see references 16 and 17). Recently, we and others have shown that two principal classes of activating signals may induce iNOS expression in mesangial cells. These two groups comprise inflammatory cytokines such as IL-1 $\beta$ or TNF- $\alpha$ (18-20) and agents that elevate cellular levels of $\operatorname{cAMP}(21,22)$. Both signal transduction pathways act on the transcription rate of the iNOS gene and subsequently increase iNOS mRNA steady state and protein levels (21).

Growth factors such as PDGF and basic fibroblast growth factor (bFGF) have been identified as important mediators in the rat model of mesangial proliferative Thy 1.1 nephritis, with bFGF being associated with the mesangiolytic phase and PDGF with the proliferative of the disease (23, for reviews see references 24-26). The aim of this study was to evaluate whether PDGF-BB and bFGF modulate induction of iNOS in mesangial cells. We show that PDGF-BB decreases IL-1 $\beta$-induced iNOS expression but has no effect on cAMP-stimulated iNOS induction. In contrast, bFGF potentiates IL-1 $\beta$ - and cAMPinduced iNOS expression. These data may provide new insights in the understanding of basic mechanisms of NO function in the pathogenesis of Thy 1.1 glomerulonephritis and other types of progressive glomerular diseases.

\section{Methods}

Cell culture. Rat mesangial cells were cultured as described previously (20). In a second step, single cells were cloned by limited dilution using 96-microwell plates. Clones with apparent mesangial cell morphology were used for further processing. The cells exhibited the typical stellate morphology. Moreover, there was positive staining for the intermediate filaments desmin and vimentin, which are considered to be specific for myogenic cells, positive staining for Thy 1.1 antigen, and negative staining for the Factor VIII-related antigen and cytokeratin, excluding endothelial and epithelial contamination, respectively. The generation of inositol trisphosphate upon activation of the angiotensin $\mathrm{II}_{\mathrm{AT}_{1}}$ receptor was used as a functional criterion for characterizing the cloned cell line. The cells were grown in RPMI 1640 supplemented with $10 \%$ FCS, penicillin (100 U/ml), streptomycin $(100 \mu \mathrm{g} / \mathrm{ml})$, and bovine insulin at $0.66 \mathrm{U} / \mathrm{ml}$ (Sigma, Buchs, Switzerland). For the experiments, passages $6-16$ of mesangial cell were used.

Nitrite analysis. Nitrite production by rat glomerular mesangial cells was measured as a read-out for NOS activity as described previously (27). Confluent mesangial cells in 24-well plates were washed twice with PBS and incubated in DMEM without phenol red and sup- plemented with $0.1 \mathrm{mg} / \mathrm{ml}$ of fatty acid-free BSA, with or without agents for the indicated time periods. Thereafter, the medium was withdrawn and nitrite was measured by mixing $200 \mu$ l of the supernatant with $100 \mu \mathrm{l}$ of Griess reagent. The absorbance at $550 \mathrm{~nm}$ was measured and the nitrite concentration was determined using a calibration curve with sodium nitrite standards.

Western blot analysis. Confluent mesangial cells were stimulated with agents for $24 \mathrm{~h}$ and then washed with PBS and scraped into $1 \mathrm{ml}$ of buffer A (50 mM Tris/HCl, pH 7.4, 0.5 mM EDTA, 0.5 mM EGTA, $1 \mu \mathrm{M}$ leupeptin, $0.1 \mathrm{mM}$ PMSF, $1 \mathrm{mM}$ dithiothreitol). Cells were homogenized in a Dounce homogenizer and centrifuged at $200,000 \mathrm{~g}$ for $30 \mathrm{~min}$ at $4^{\circ} \mathrm{C}$. Protein concentration was determined by the method of Bradford (28). The supernatants ( $3 \mathrm{mg}$ of protein) were incubated for $30 \mathrm{~min}$ at $4^{\circ} \mathrm{C}$ with $400 \mu \mathrm{l}$ of a $1: 1$ ( $\mathrm{vol} / \mathrm{vol}$ ) slurry of $2^{\prime}, 5^{\prime}$-ADPagarose in buffer A with gentle agitation. After centrifugation for 10 min at 3,000 $g$ the pellets were washed twice with buffer A, once with buffer A containing $0.5 \mathrm{M} \mathrm{NaCl}$, and finally with buffer A only. The proteins were solubilized from the beads by heating for $5 \mathrm{~min}$ at $95^{\circ} \mathrm{C}$ in $0.1 \mathrm{ml}$ of SDS-PAGE sample buffer $(3.6 \%$ [wt/vol] SDS, $15 \%$ [wt/ vol] glycerol, $120 \mathrm{mM}$ Tris-HCl, pH 6.8, 0.125 M DTT) and subjected to SDS-PAGE (7.5\% acrylamide gel). Immunoblotting was performed as described using a polyclonal anti-iNOS antibody (29) at a dilution of 1:1,000.

Northern blot analysis. Confluent mesangial cells were washed twice with PBS and incubated in DMEM, supplemented with $0.1 \mathrm{mg} / \mathrm{ml}$ of fatty acid-free BSA, with or without agents for the indicated time periods. Cells were washed twice with PBS and harvested using a rubber policeman. Total cellular RNA was extracted from the cell pellets using the guanidinium thiocyanate/cesium chloride method (30). Samples of $20 \mu \mathrm{g}$ RNA were separated on 1\% (wt/vol) agarose gels containing $0.66 \mathrm{M}$ formaldehyde before the transfer to GeneScreen membranes (New England Nuclear, Boston, MA). After UV crosslinking and prehybridization for $2 \mathrm{~h}$, the filters were hybridized for 16-18 $\mathrm{h}$ to a ${ }^{32} \mathrm{P}$-labeled SmaI cDNA insert from pMac-NOS. To correct for variation in RNA amount, the NOS probe was stripped with boiling $0.1 \times \mathrm{SSC} / 1 \%$ SDS and the blots were rehybridized to the ${ }^{32} \mathrm{P}$-labeled BamHI/SalI cDNA insert from clone pEX 6 coding for human $\beta$-actin. DNA probes $\left(0.5-1 \times 10^{6} \mathrm{dpm} / \mathrm{ml}\right)$ were radioactively labeled with $\left[{ }^{32} \mathrm{P}\right] \mathrm{dATP}$ by random priming (Boehringer Mannheim, Mannheim, Germany). Hybridization reactions were performed in $50 \%(\mathrm{vol} / \mathrm{vol})$ formamide, $5 \times \mathrm{SSC}, 5 \times$ Denhardt's solution, $1 \%(\mathrm{wt} /$ vol) SDS, $10 \%$ (wt/vol) dextran sulfate, and $100 \mu \mathrm{g} / \mathrm{ml}$ salmon sperm DNA. Filters were washed three times in $2 \times \mathrm{SSC} / 0.1 \%$ SDS at room temperature for $15 \mathrm{~min}$, and then twice in $0.2 \times \mathrm{SSC} / 1 \% \mathrm{SDS}$ at $65^{\circ} \mathrm{C}$ for $30 \mathrm{~min}$. Filters were exposed for $24-48 \mathrm{~h}$ to Kodak X-Omat XAR film using intensifying screens.

Nuclear run-on transcription. For preparation of nuclei, $\sim 5 \times$ $10^{7}$ cells were lysed in ice-cold RSB $(10 \mathrm{mM}$ Tris- $\mathrm{HCl}, \mathrm{pH} 7.4,5 \mathrm{mM}$ $\mathrm{KCl} / 3 \mathrm{mM} \mathrm{MgCl}_{2}$ ) containing $0.5 \%$ Nonidet P-40. Nuclei were isolated by spinning at $800 \mathrm{~g}$, washed once in ice-cold PBS, and finally resuspended in $40 \%$ (vol/vol) glycerol $/ 50 \mathrm{mM}$ Hepes ( $\mathrm{pH} 8.0) / 5 \mathrm{mM}$ $\mathrm{MgCl}_{2} / 2 \mathrm{mM}$ dithiothreitol. For the run-on transcription assay, the nuclei suspension was mixed with $0.2 \mathrm{ml}$ of $2 \times$ reaction buffer $(100 \mathrm{mM}$ Hepes [pH 8.0]/10 mM MgCl$/ 300 \mathrm{mM} \mathrm{KCl} / 200 \mathrm{U} / \mathrm{ml} \mathrm{RNasin)} \mathrm{(Boeh-}$ ringer Mannheim), $1 \mathrm{mM}$ each ATP, GTP, and CTP/150 $\mu \mathrm{Ci}(1 \mu \mathrm{Ci}=$ $37 \mathrm{kBq})$ of $\left.{ }^{32} \mathrm{P}\right] \mathrm{UTP}(3,000 \mathrm{Ci} / \mathrm{mmol})$ and incubated for $30 \mathrm{~min}$ at $37^{\circ} \mathrm{C}$. Transcription was stopped by adding $20 \mu \mathrm{g}$ of DNase I, followed by $80 \mu \mathrm{g}$ of proteinase $\mathrm{K}$. The ${ }^{32} \mathrm{P}$-labeled RNA was purified by extraction with phenol/chloroform and two sequential precipitations with ammonium acetate. Equal amounts of labeled RNA $\left(8 \times 10^{7}\right.$ $\mathrm{dpm} / \mathrm{ml}$ ) were hybridized in $50 \%$ formamide $/ 5 \times \mathrm{SSC} / 5 \times$ Denhardt's solution $/ 1 \%$ SDS $(1 \times \mathrm{SSC}=150 \mathrm{mM} \mathrm{NaCl} / 15 \mathrm{mM}$ sodium citrate, $\mathrm{pH} 7.0$ ) at $42^{\circ} \mathrm{C}$ for $72 \mathrm{~h}$. Filters contained $10 \mu \mathrm{g}$ each of linearized plasmids immobilized on GeneScreen membranes after blotting in $12 \times$ SSPE with a dot-blot apparatus. After hybridization filters were rinsed for $30 \mathrm{~min}$ in $2 \times \mathrm{SSC}$ at $60^{\circ} \mathrm{C}$, for $5 \mathrm{~min}$ in $2 \times \mathrm{SSC}$ containing $10 \mathrm{mg} / \mathrm{ml}$ of RNase A at $37^{\circ} \mathrm{C}$, and finally for $1 \mathrm{~h}$ in $2 \times \mathrm{SSC}$ at $37^{\circ} \mathrm{C}$. Filters were air dried and exposed at $-70^{\circ} \mathrm{C}$ for $2-6 \mathrm{~d}$. 
Cell death detection by analysis of cytosolic oligonucleosomebound DNA. Confluent mesangial cells in 35-mm-diameter dishes were washed twice with PBS and incubated in DMEM. Cytosolic oligonucleosome-bound DNA was quantitated using an ELISA kit (Boehringer Mannheim) with a primary antihistone antibody and a secondary anti-DNA antibody coupled to peroxidase according to the manufacturer's instructions. Absorbance values $\left(\mathrm{A}_{450 \mathrm{~nm} / 486 \mathrm{~nm}}\right)$ are a relative measure for DNA fragmentation. Percentage of fragmentation is expressed in comparison to controls.

Cell fractionation for immunodetection of protein kinase $C(P K C)$. Stimulated mesangial cells were washed with ice-cold PBS (137 mM $\mathrm{NaCl} / 2.7 \mathrm{mM} \mathrm{KCl} / 8 \mathrm{mM} \mathrm{Na}_{2} \mathrm{HPO}_{4} / 1.5 \mathrm{mM} \mathrm{KH}_{2} \mathrm{PO}_{4}$ ) and scraped into $0.5 \mathrm{ml}$ of ice-cold homogenization buffer $(20 \mathrm{mM}$ Tris- $\mathrm{HCl}[\mathrm{pH}$ 7.5]/1 mM EDTA/1 mM EGTA/2 mM dithiothreitol/25 $\mu \mathrm{g}$ of leupeptin per $\mathrm{ml} / 1 \mathrm{mM} \mathrm{PMSF} / 10 \mathrm{mM}$ benzamidine) with a rubber policeman. All subsequent steps were carried out at $4^{\circ} \mathrm{C}$. The cells were lysed with $3 \times 10$-s bursts with a sonifier (setting 4.0, model B15; Branson Ultrasonics Corp., Danbury, CT) and centrifuged for $1 \mathrm{~h}$ at $100,000 \mathrm{~g}$. Supernatants were used as a source of cytosolic protein. Pellets were resonicated in $1 \mathrm{ml}$ of the same buffer containing $1 \%$ (vol/vol) Triton X-100 and centrifuged for $1 \mathrm{~h}$ at 100,000 $\mathrm{g}$, yielding the solubilized particulate fractions. Protein concentration was determined by the method of Bradford (28). Generation and characterization of PKC isoenzyme-specific antibodies has been reported previously $(31,32)$.

Chemicals. Recombinant human IL-1 $\beta$ was generously supplied by Dr. C. Rordorf (Novartis Pharma Inc., Basel, Switzerland); $N^{6}, O-2^{\prime}$-dibutyryladenosine $3^{\prime}, 5^{\prime}$-phosphate $\left(\mathrm{Bt}_{2} \mathrm{cAMP}\right)$ was from Sigma; PDGF-BB was a kind gift of Dr. Michael Pech (F. HoffmannLa Roche Ltd., Basel, Switzerland); ( $\operatorname{ser}^{70,88}$ )bFGF was generously supplied by Dr. Michael Fox (Amgen Inc., Thousand Oaks, CA); the cDNA clone pMac-NOS, coding for the inducible macrophage NOS was kindly provided by Dr. J. Cunningham (Boston, MA); and the cDNA clone pEX 6, coding for human $\beta$-actin, was a gift from Dr. U. Aebi (Maurice E. Müller Institut, Basel, Switzerland). The genomic clone coding for $28 \mathrm{~S}$ ribosomal RNA was kindly provided by Dr. Th. Geiger (Novartis Pharma Inc., Basel, Switzerland), the cDNA clone coding for murine IL-1 type I receptor was a gift from Dr. C. Dinarello (Denver, CO); Nylon membranes (GeneScreen) were purchased from DuPont de Nemours International (Regensdorf, Switzerland); $\left.{ }^{32} \mathrm{P}\right] \mathrm{dATP}$ (specific activity $3,000 \mathrm{Ci} / \mathrm{mmol}$ ) was from Amersham (Dübendorf, Switzerland); calphostin C was purchased from Anawa (Dübendorf, Switzerland); cell culture media and nutrients were from Gibco BRL (Basel, Switzerland); and all other chemicals were either from Merck (Darmstadt, Germany) or Fluka (Buchs, Switzerland). Antibodies specific for iNOS were generated using the multiple antigen peptide (MAP) system. The peptide antigen based on an $\mathrm{NH}_{2}-$ terminal sequence of mouse iNOS (NVPESLDKLHVT) is assembled stepwise on the MAP core resin. After complete peptide assembly, the MAP system is cleaved from the resin support and after dialysis is used for immunization (29).

\section{Results}

IL-1 $\beta$-induced iNOS activity is differentially affected by PDGF$B B$ and $b F G F$. Mesangial cells were incubated with IL-1 $\beta$ and cell culture supernatants were assayed for nitrite production, one of the stable end products of NO formation. Only low amounts of NO (14 $\pm 7 \mathrm{nmol}$ nitrite $/ \mathrm{mg}$ of protein) are produced in unstimulated mesangial cells. Treatment with IL-1 $\beta$ $(2 \mathrm{nM})$ for $24 \mathrm{~h}$ dramatically induces the production of NO by $\sim 44$-fold $(617 \pm 49 \mathrm{nmol}$ nitrite $/ \mathrm{mg}$ of protein, mean $\pm \mathrm{SD}$, $n=4)$.

Treatment of mesangial cells with PDGF-BB dose-dependently inhibits the formation of nitrite induced by IL- $1 \beta$ with a half-maximal inhibitory concentration $\left(\mathrm{IC}_{50}\right)$ of $4.2 \pm 0.4 \mathrm{ng} / \mathrm{ml}$
PDGF-BB (mean \pm SD, $n=3$ ) and maximal inhibition at 100 $\mathrm{ng} / \mathrm{ml}$, thus confirming previous observations (33). In contrast, bFGF dose-dependently superinduces IL-1 $\beta$-dependent nitrite production with significant effects already at $3 \mathrm{ng} / \mathrm{ml}$ bFGF and a maximal potentiation by $53 \pm 12 \%$ (mean $\pm \mathrm{SD}, n=$ 3) at $100 \mathrm{ng} / \mathrm{ml} \mathrm{bFGF}$.

The experiments described here have been performed with $\left(\operatorname{ser}^{70,88}\right)$ bFGF in which cysteine residues at positions 70 and 88 , which are not conserved among the FGF family members, have been replaced with serines in order to reduce intermolecular dimer formation at high protein concentration. This molecule has biological activity identical to that of native bFGF (34). Selected experiments have been performed with native bFGF (Boehringer Mannheim) and gave identical results.

Modulation of IL-1 $\beta$-induced iNOS activity by PDGF-BB and $b F G F$ is due to changes in iNOS protein and $m R N A$ levels. Western blot analysis with an iNOS-specific polyclonal antibody demonstrates that treatment of mesangial cells with IL-1 $\beta$ drastically upregulates the $130-\mathrm{kD}$ iNOS protein as shown in Fig. 1. This band is not detectable in unstimulated mesangial cells and also the growth factors PDGF-BB and bFGF alone have no effect on iNOS protein expression (Fig. 1). Coincubation of cells with IL-1 $\beta$ and PDGF-BB potently reduces iNOS protein levels, whereas bFGF strongly potentiates formation of iNOS protein (Fig. 1).

To assess whether the modulation of IL-1 $1 \beta$-induced iNOS protein levels by PDGF-BB and bFGF is associated with changes in the corresponding mRNA steady state levels coding for iNOS, Northern blot analyses were performed. As shown in Fig. $2 A$, IL-1 $\beta$-induced iNOS mRNA steady state levels are reduced by PDGF-BB in a dose-dependent fashion, whereas bFGF strongly augments IL- $1 \beta$-stimulated iNOS mRNA steady state levels (Fig. $2 \mathrm{~B}$ ). The different intensity of the IL-1 $\beta$ signal is intended and is due to different exposure times of $2 \mathrm{~h}$ (Fig. $2 \mathrm{~B}$ ) and overnight (Fig. $2 \mathrm{~A}$ ) in order to allow optimal evaluation of the stimulatory and inhibitory effects of bFGF and PDGF-BB, respectively.

$P D G F-B B$ and $b F G F$ differentially modulate $I L-1 \beta$-induced $i N O S$ gene transcription in mesangial cells. Nuclear run-on experiments were performed to evaluate whether changes in iNOS gene transcription may contribute to the observed changes in iNOS mRNA steady state levels. As shown in Fig. 3 , in unstimulated mesangial cells virtually no transcriptional

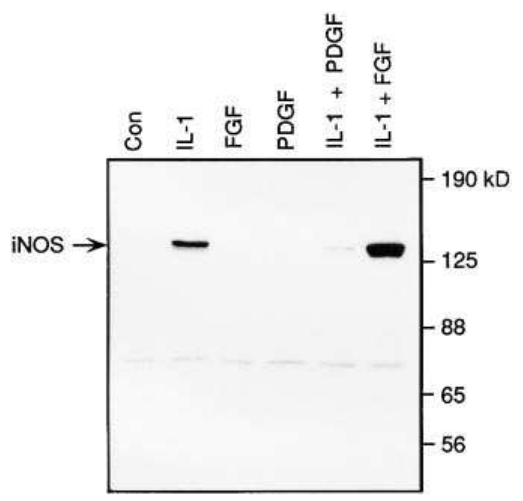

Figure 1. Effects of PDGF-BB and bFGF on IL-1 $\beta$-stimulated iNOS protein levels in mesangial cells. Mesangial cells were incubated for $24 \mathrm{~h}$ with vehicle (Con), IL-1 $\beta$ ( $2 \mathrm{nM})$, bFGF $(100 \mathrm{ng} / \mathrm{ml})$, PDGF-BB (100 ng/ml), IL-1 $\beta(2 \mathrm{nM})$ plus PDGF-BB (100 ng/ml), or IL-1 $\beta(2 \mathrm{nM})$ plus bFGF $(100 \mathrm{ng} / \mathrm{ml})$ as indicated. Samples were analyzed by SDS-PAGE and transferred to nitrocellulose filters. Immunoblots were developed by using anti-iNOS antiserum at a dilution of 1:1,000. The arrow indicates the position of iNOS. 
A

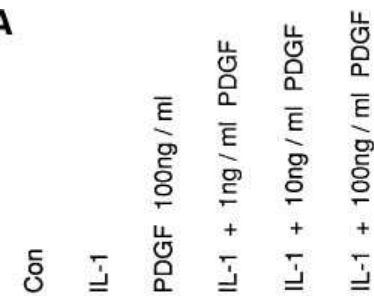

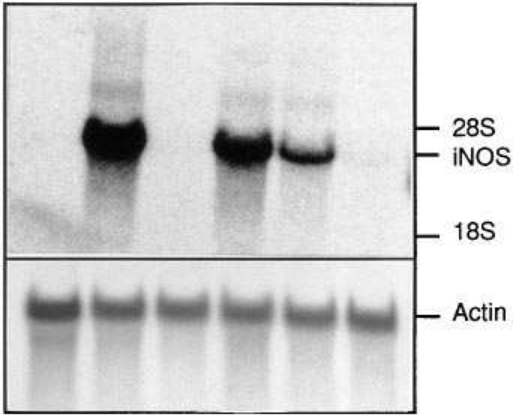

B

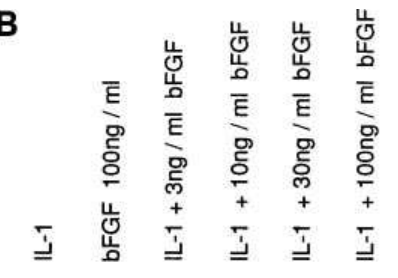

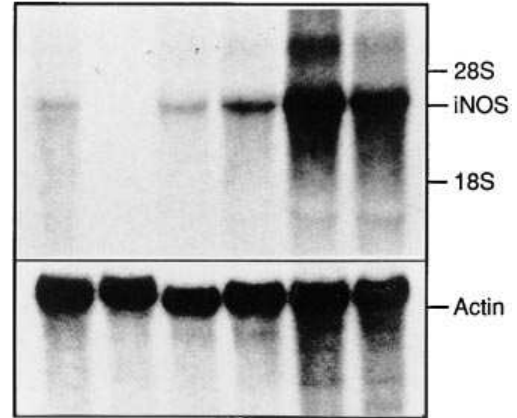

Figure 2. Modulation of IL-1 $\beta$-stimulated iNOS mRNA steady state levels in mesangial cells by PDGF-BB $(A)$ and bFGF $(B)$. Mesangial cells were incubated for $24 \mathrm{~h}$ with vehicle (Con), IL-1 $\beta(2 \mathrm{nM})$, alone or together with the indicated concentrations of PDGF-BB $(A)$ or bFGF $(B)$. Samples of $20 \mu \mathrm{g}$ of total RNA were blotted on to GeneScreen membranes which were hybridized to ${ }^{32} \mathrm{P}$-labeled iNOS cDNA. To assess for variations in RNA loading, blots were stripped and rehybridized to ${ }^{32} \mathrm{P}$-labeled $\beta$-actin cDNA probe.
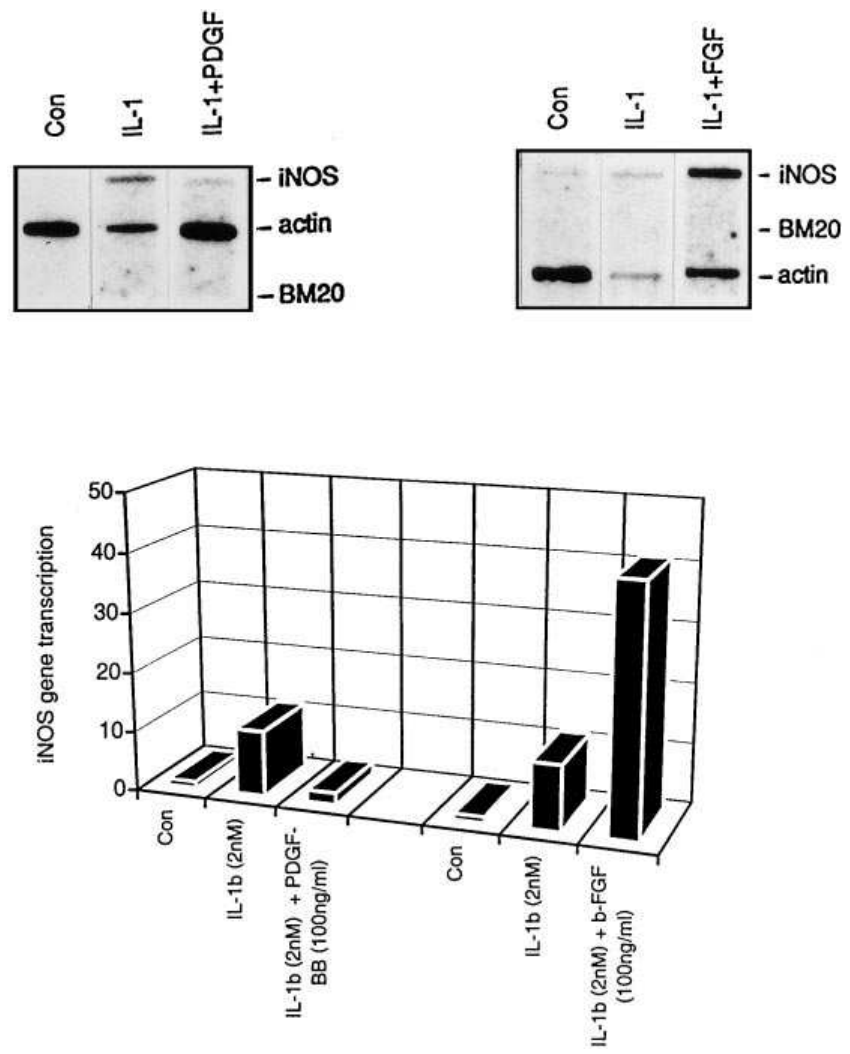

Figure 3. Effects of PDGF-BB and bFGF on IL-1 $\beta$-induced iNOS gene transcription in mesangial cells. Mesangial cells were stimulated

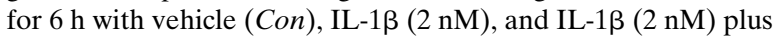
PDGF-BB (100 ng/ml) (left) or IL-1 $\beta(2 \mathrm{nM})$ plus bFGF $(100 \mathrm{ng} / \mathrm{ml})$ (right). The rate of transcription of iNOS and $\beta$-actin genes by isolated nuclei was determined by hybridizing the elongated, ${ }^{32} \mathrm{P}$-labeled RNA transcripts to iNOS cDNA, $\beta$-actin, and pSPTBM 20 probes immobilized onto nitrocellulose membranes. To correct for differences in loading, the signal intensity of each sample hybridized to the $\beta$-actin probe. The corrected data are displayed as bar graphs in the lower part of the figure. activity is detected. Incubation of cells with IL-1 $\beta$ for $6 \mathrm{~h}$ increases the transcription rate of the iNOS gene to $\sim 11$-fold (Fig. 3). PDGF-BB decreases the transcriptional activity of the iNOS gene by $\sim 90 \%$ (Fig. 3, left). Thus, the suppressive effect of PDGF-BB on iNOS expression is most likely due to an interference with the transcriptional machinery regulating iNOS gene transcription. By contrast, coincubation of the cells with bFGF drastically potentiates IL- $1 \beta$-induced transcriptional activity of the iNOS gene, from 11-fold by IL-1 $\beta$ alone, up to $\sim 41$-fold for IL-1 $\beta$ plus bFGF (Fig. 3, right). Therefore, the observed superinduction of iNOS expression upon coincubation of mesangial cells with IL- $1 \beta$ and bFGF is due to a dramatic effect on the transcription rate of the iNOS gene.

The inhibitory effect of PDGF-BB on IL-1 $\beta$-induced nitrite formation is mediated by protein kinase $C$ and is reversed by calphostin $C$. A possible explanation for the disparate effects of the two growth factors on IL-1 $\beta$-stimulated iNOS expression is the different degree of activation of PKC. Whereas PDGF-BB potently stimulates phosphoinositide turnover and subsequent activation of PKC in mesangial cells $(35,36)$, bFGF is a poor activator of this signaling pathway (Pfeilschifter, J., unpublished results). We reported earlier that mesangial cells express four PKC isoenzymes $(\alpha, \delta, \epsilon, \zeta)(31,32$, 37). For the classical and novel PKC isotypes, increased association with the membrane fraction and concomitant loss from the soluble fraction is called "translocation" and is equated with activation (38). As shown in Fig. 4, PDGF-BB triggers translocation of PKC- $\alpha$, $-\delta$, and $-\epsilon$ isoenzymes, leaving PKC- $\zeta$ unaffected. Moreover, PDGF-BB downregulates PKC- $\delta$ and less pronounced also $\mathrm{PKC}-\alpha$ after $30 \mathrm{~min}$ of incubation. In contrast, bFGF only weakly induces PKC- $\alpha$ translocation without affecting PKC- $\delta,-\epsilon$, and $-\zeta$ isoenzymes (Fig. 4), thus confirming the previous observation on a different degree of PKC activation by the two growth factors. To evaluate whether the inhibitory effect of PDGF-BB on iNOS expression is mediated by $\mathrm{PKC}$ we used calphostin $\mathrm{C}$, a potent and specific inhibitor of PKC (39). Mesangial cells were incubated for $24 \mathrm{~h}$ with IL-1 $\beta$ and PDGF-BB in the presence or absence of calphostin C. 

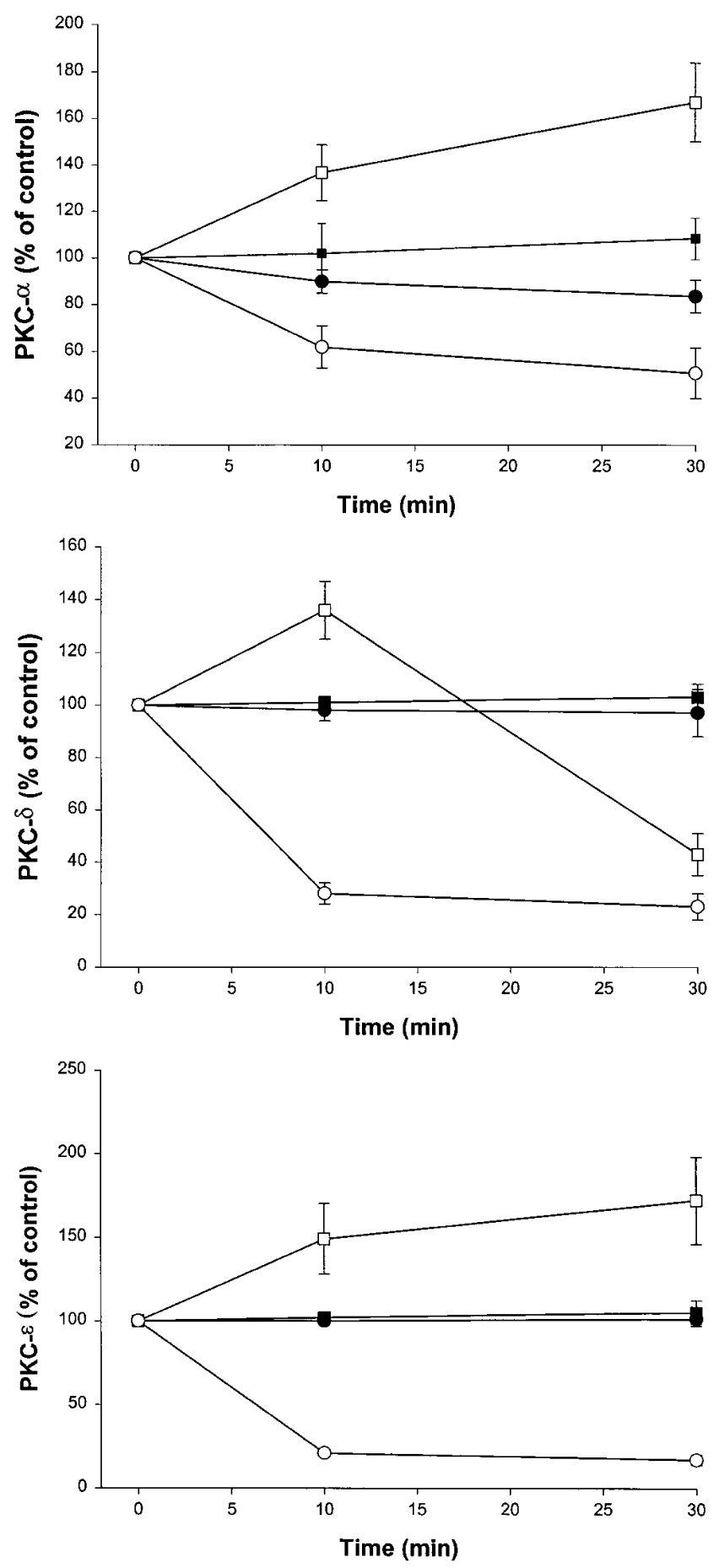

Figure 4. Effect of PDGF-BB and bFGF on translocation of PKC isoenzymes in mesangial cells. Confluent mesangial cells were stimulated for the indicated time periods ( $\mathrm{min})$ with PDGF-BB $(30 \mathrm{ng} / \mathrm{ml}$; open symbols) or bFGF (30 ng/ml; closed symbols), and the cytosolic and particulate fractions were prepared. Samples (100 $\mu \mathrm{g}$ of protein) were subjected to SDS-PAGE ( $8 \%$ acrylamide gel), transferred to nitrocellulose, and Western blot analysis was performed using specific polyclonal antibodies against PKC- $\alpha(1: 100)$, PKC- $\delta(1: 1,000)$, and PKC- $\epsilon(1: 1,000)$. Bands were detected with horseradish peroxidase and densitometrically evaluated. Results are expressed as percentage of the respective control values and are means \pm SD of three independent experiments.
Subsequently cell culture supernatants were assayed for nitrite. As shown in Fig. 5, calphostin $\mathrm{C}$ almost completely reverses the inhibitory effect of PDGF-BB on IL-1 $\beta$-induced formation of nitrite. Thus, the inhibitory action of PDGF-BB on iNOS expression is indeed most likely mediated by the activation of PKC. A possible target for PKC that eventually could result in inhibition of iNOS expression is the IL-1 receptor $(40,41)$ which was examined next.

bFGF, but not PDGF-BB, affects IL-1 $\beta$-induced IL-1 type I receptor $m R N A$ levels. To determine whether IL-1 type I receptor mRNA steady state levels are affected by the action of the growth factors, Northern blot analyses were performed. Mesangial cells were incubated for $24 \mathrm{~h}$ with IL- $1 \beta$ in the presence of PDGF-BB or bFGF. Subsequently, polyA-RNA was isolated and used for Northern blot analysis. As shown in Fig. 6 , in unstimulated mesangial cells only a minor signal is detected. Incubation with IL-1 $\beta$ increases IL-1 type I receptor mRNA levels by about fivefold as compared with control cells. Coincubation of cells with IL-1 $\beta$ and PDGF-BB does not change IL-1 type I receptor mRNA levels (Fig. 6). In contrast, incubation of cells with IL- $1 \beta$ in the presence of bFGF drastically increases steady state mRNA levels of IL-1 type I receptor by $\sim 17$-fold (Fig. 6 ).

cAMP-induced iNOS activity is differentially modulated by $P D G F-B B$ and $b F G F$. A second class of stimuli besides inflammatory cytokines that have been shown to induce expression of iNOS in mesangial cells are cAMP-elevating agents (21, 22). Therefore, we incubated mesangial cells with $\mathrm{Bt}_{2} \mathrm{cAMP}, \mathrm{a}$ membrane-permeant analogue of cAMP, together with increasing amounts of PDGF-BB or bFGF for $24 \mathrm{~h}$ and cell culture supernatants assayed for nitrite production. $\mathrm{Bt}_{2} \mathrm{cAMP}$ $(10 \mathrm{mM})$ increases nitrite production by 33 -fold $(462 \pm 28$ $\mathrm{nmol} / \mathrm{mg}$ of protein; mean $\pm \mathrm{SD}, n=4)$ as compared with control cells $(14 \pm 7 \mathrm{nmol} / \mathrm{mg}$ of protein). Treatment of mesangial

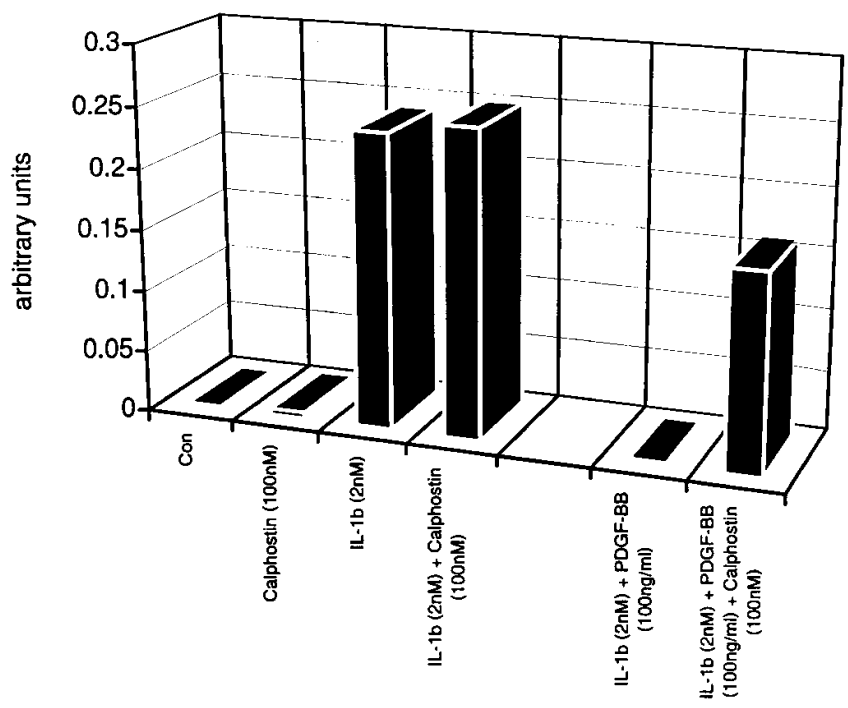

Figure 5. Effect of calphostin C on PDGF-BB inhibition of IL-1 $\beta-$ stimulated nitrite formation in mesangial cells. Mesangial cells were incubated for $24 \mathrm{~h}$ with vehicle (Con), IL-1 $\beta$ in the absence or presence of PDGF-BB, or calphostin $\mathrm{C}$ as indicated. Thereafter, the medium was removed and used for nitrite determination. Data represent means of four independent experiments. 

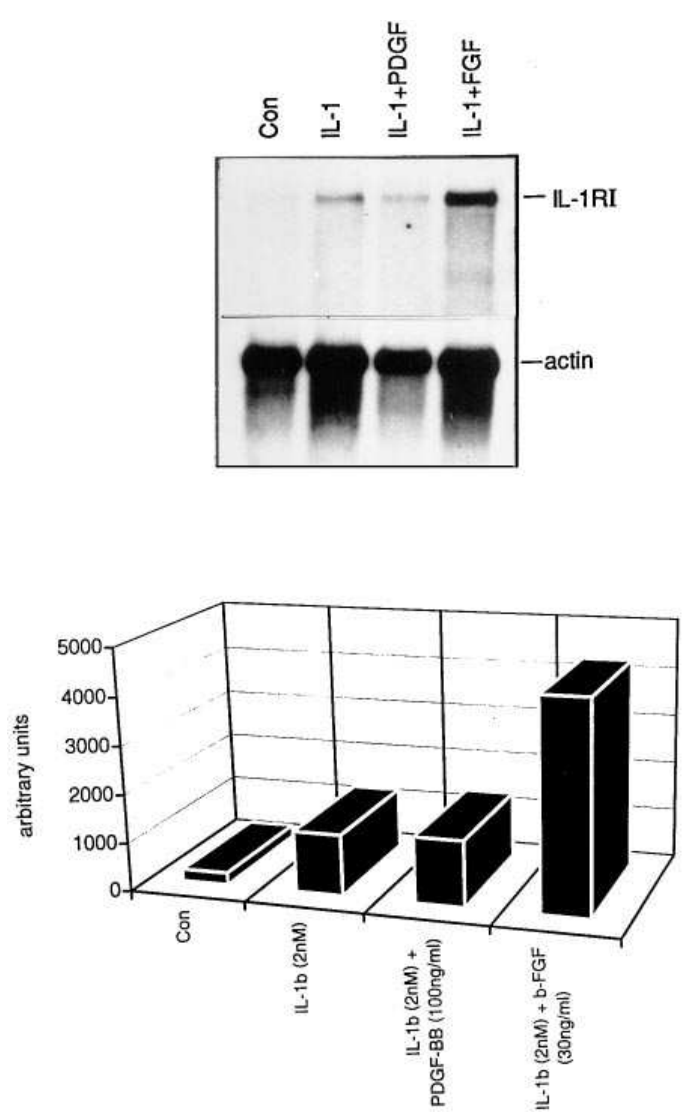

Figure 6. Effect of PDGF-BB and bFGF on IL-1 type I receptor mRNA levels in mesangial cells. Mesangial cells were incubated with vehicle (Con), IL-1 $\beta$ ( $2 \mathrm{nM})$, IL-1 $\beta$ ( $2 \mathrm{nM}$ ) plus PDGF-BB (30 ng/ml), or IL-1 $\beta(2 \mathrm{nM})$ plus bFGF $(30 \mathrm{ng} / \mathrm{ml})$ for $24 \mathrm{~h}$. Samples of 3-5 $\mu \mathrm{g}$ of poly A-RNA were blotted on to GeneScreen membranes and were hybridized to ${ }^{32} \mathrm{P}$-labeled IL-1 type I receptor cDNA. To assess for variations in RNA loading, blots were stripped and rehybridized to ${ }^{32} \mathrm{P}$-labeled $\beta$-actin cDNA probe. The densitometrical analysis, based on $\beta$-actin hybridization. is shown in the bottom part of the figure and represents the means of two independent experiments.

cells with PDGF-BB virtually does not affect cAMP-induced production of nitrite (data not shown). By contrast, bFGF amplifies the formation of nitrite by mesangial cells by $\sim 75 \%$, as shown in Fig. 7.

Modulation of $c A M P$-induced iNOS activity by PDGF-BB and $b F G F$ is due to changes in iNOS protein and $m R N A$ levels. Western blot analysis demonstrates that treatment of mesangial cells with $\mathrm{Bt}_{2} \mathrm{cAMP}$ for $24 \mathrm{~h}$ upregulates the $130-\mathrm{kD}$ iNOS protein as shown in Fig. 8. Coincubation of cells with $\mathrm{Bt}_{2} \mathrm{cAMP}$ and PDGF-BB for $24 \mathrm{~h}$ does not alter iNOS protein levels (Fig. 8). By contrast, incubation of mesangial cells with $\mathrm{Bt}_{2} \mathrm{cAMP}$ in the presence of bFGF enhances cAMP-induced expression of iNOS protein (Fig. 8). To assess whether the modulation of cAMP-induced iNOS protein levels by PDGF-BB and bFGF was associated with changes in the corresponding mRNA steady state levels coding for iNOS, Northern blot analyses were performed. Whereas cAMP-induced iNOS mRNA steady state levels are not significantly affected by PDGF-BB (data not shown), bFGF strongly potentiates $\mathrm{Bt}_{2} \mathrm{cAMP}$-stimulated iNOS mRNA steady state levels as shown in Fig. 9.

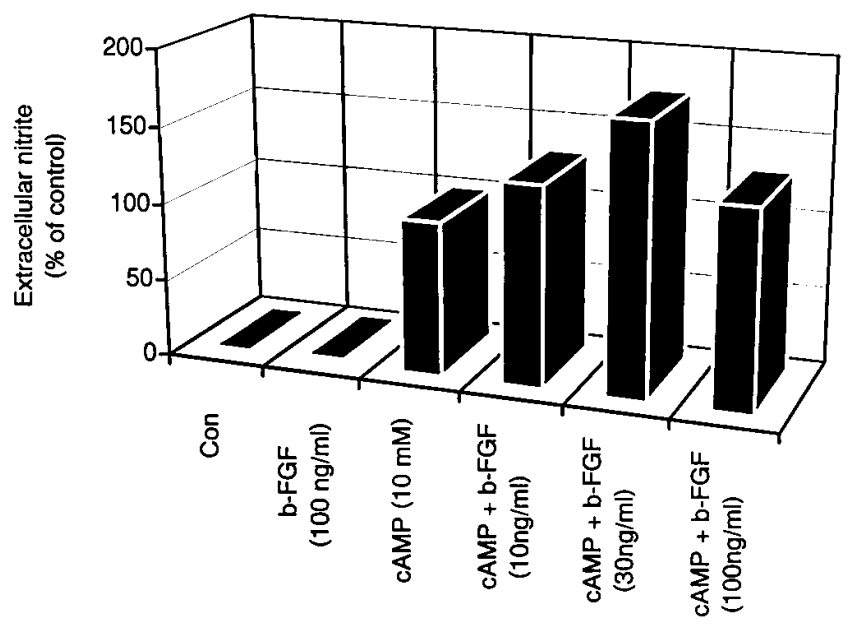

Figure 7. Superinduction of cAMP-stimulated nitrite formation in mesangial cells by bFGF. Mesangial cells were incubated for $24 \mathrm{~h}$ with vehicle (Con), bFGF, $\mathrm{Bt}_{2} \mathrm{cAMP}(c A M P)$, and $\mathrm{Bt}_{2} \mathrm{cAMP}$ plus the indicated concentrations of bFGF. Thereafter, the medium was removed and used for nitrite determination. Data represent means of four independent experiments.

$P D G F-B B$ and $b F G F$ differentially modulate $c A M P$-induced iNOS gene transcription in mesangial cells. Nuclear run-on experiments were performed to evaluate whether changes in iNOS gene transcription may contribute to the observed changes in iNOS mRNA steady state levels. Incubation of cells with $\mathrm{Bt}_{2} \mathrm{cAMP}$ for $6 \mathrm{~h}$ increases the transcription rate of the iNOS gene by about sevenfold (Fig. 10). Whereas PDGF-BB only causes a minor decrease in the transcriptional activity of the iNOS gene, bFGF potentiates cAMP-induced transcriptional activity of the iNOS gene, from 7-fold induction by $\mathrm{Bt}_{2} \mathrm{cAMP}$ alone, up to $\sim 11$-fold for $\mathrm{Bt}_{2} \mathrm{cAMP}$ plus bFGF (Fig. 10). Therefore, the observed superinduction of iNOS expression upon coincubation of mesangial cells with cAMP and bFGF is most likely due to an increase in the transcription rate of the iNOS gene.

bFGF triggers $\mathrm{NO}$-dependent apoptosis of mesangial cells. We have reported previously that NO delivered from exogenously applied NO donors causes apoptosis of mesangial cells (42). Surprisingly, endogenously produced NO in IL-1 $\beta$-stim-

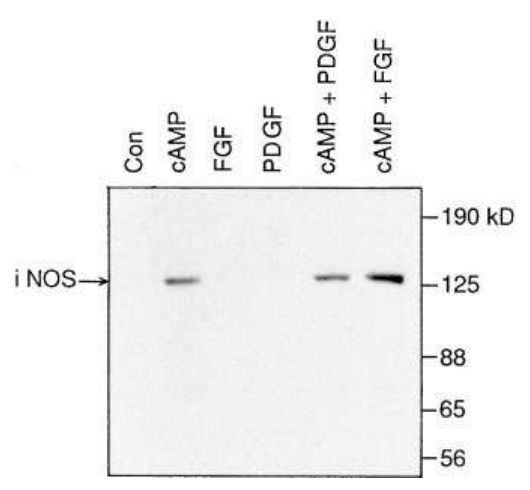

Figure 8. Effects of PDGF-BB and bFGF on cAMP-stimulated iNOS protein in mesangial cells. Mesangial cells were incubated for $24 \mathrm{~h}$ with vehicle (Con), $\mathrm{Bt}_{2} \mathrm{cAMP}(10 \mathrm{mM})$, bFGF $(100 \mathrm{ng} / \mathrm{ml})$, PDGF-BB (100 ng/ml), $\mathrm{Bt}_{2} \mathrm{CAMP}(10 \mathrm{mM})$ plus PDGF-BB (100 ng/ml), or $\mathrm{Bt}_{2} \mathrm{CAMP}(10 \mathrm{mM})$ plus bFGF $(100 \mathrm{ng} / \mathrm{ml})$.

Samples were analyzed by SDS-PAGE and transferred to nitrocellulose filters. Immunoblots were developed by using anti-iNOS antiserum at a dilution of 1:1,000. The arrow indicates the position of iNOS. 


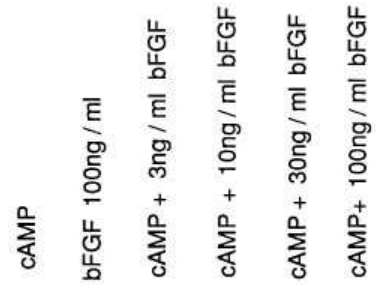

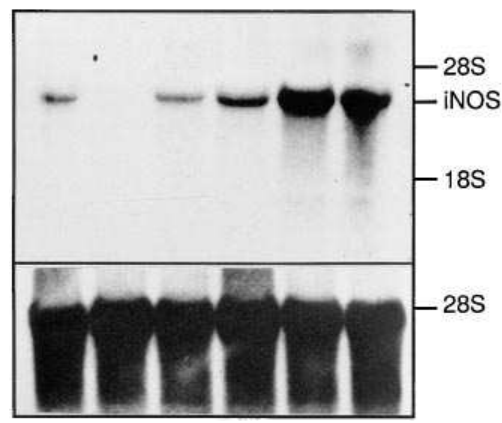

Figure 9. Superinduction of cAMP-stimulated iNOS mRNA steady state levels in mesangial cells by bFGF Mesangial cells were incubated for $24 \mathrm{~h}$ with $\mathrm{Bt}_{2} \mathrm{cAMP}(10 \mathrm{mM})$, bFGF (100 ng/ml), and $\mathrm{Bt}_{2} \mathrm{cAMP}(10 \mathrm{mM})$ plus the indicated concentrations of bFGF. Samples of $20 \mu \mathrm{g}$ of total RNA were blotted onto GeneScreen membranes which were hybridized to ${ }^{32} \mathrm{P}$-labeled iNOS cDNA. To assess for variations in RNA loading, blots were stripped and rehybridized to ${ }^{32} \mathrm{P}$ labeled $28 \mathrm{~S}$ ribosomal RNA probe.

ulated mesangial cells did not cause programmed cell death but instead even protected the cells (43). The reason for this unexpected finding was a balanced formation of $\mathrm{NO}$ and $\mathrm{O}_{2}{ }^{-}$ in cytokine-exposed mesangial cells. However, a disturbance of this balance of radicals by surplus NO delivered from exogenous sources or within the cell indeed promotes mesangial cell death again (44). To evaluate whether the potentiating effect of bFGF on IL-1 $\beta$-induced NO production is functionally relevant for triggering mesangial cell death, we measured the formation of cytosolic oligonucleosome-bound DNA complexes, an established marker of apoptosis (42). As shown in Fig. 11, incubation of mesangial cells with either IL-1 $\beta$ or bFGF alone does not cause DNA fragmentation. However, a coincubation of cells with IL-1 $\beta$ and bFGF evokes a marked increase in cytosolic histone-DNA complexes (Fig. 11). This increased rate of apoptosis is NO mediated as evidenced by the fact that the potent NOS inhibitor L-NMMA completely blocks DNA fragmentation in response to IL-1 $\beta$ plus bFGF stimulation (Fig. 11). Parallel changes were observed when monitoring morphological apoptotic alterations by staining of nuclei with Hoe-33258 dye (data not shown).

\section{Discussion}

In recent years strong evidence was provided that NO is a messenger molecule involved in the regulation of physiological processes in the kidney, but is also an important mediator in the pathogenesis of several inflammatory glomerular diseases. As for many other vascular beds, a role for NO in the control of arteriolar resistance in the kidney has been proposed. Application of the nonmetabolizable L-arginine analogue L-NMMA causes inhibition of $\mathrm{NO}$ formation and reduction in renal blood flow (45) and glomerular filtration rate in rats (46). Thus, NO seems to maintain the systemic and renal vasculature in a state of active vasodilatation. Moreover, NO has direct effects on renal tubular functions and increases sodium excretion independent of its changes in renal blood flow (46). Recent studies have shown that neuronal NOS is abundantly expressed in macula densa cells $(47,48)$ and NO produced by these cells may act in concert with various other vasoactive substances to regulate glomerular hemodynamics and renin release in response to changes in the composition of tubular fluid.

There is ample evidence for the involvement of the L-arginine/NO pathway in the development of several forms of glomerulonephritis, including rat mesangial proliferative anti-Thy 1.1 glomerulonephritis (for reviews see references 5 and 6). Moreover, iNOS expression in vivo in rat kidneys with acute immune complex-mediated glomerulonephritis has been demonstrated by immunohistochemistry and in situ hybridization (49). Expression of iNOS mRNA in accelerated nephrotoxic nephritis was studied by quantitative RT-PCR. iNOS expression was present at low levels in normal glomeruli and was markedly enhanced within $6 \mathrm{~h}$ after the induction of glomerulonephritis and peaked at $24 \mathrm{~h}$. Elevated levels of iNOS mRNA persisted to day 7 (50). These were the first studies
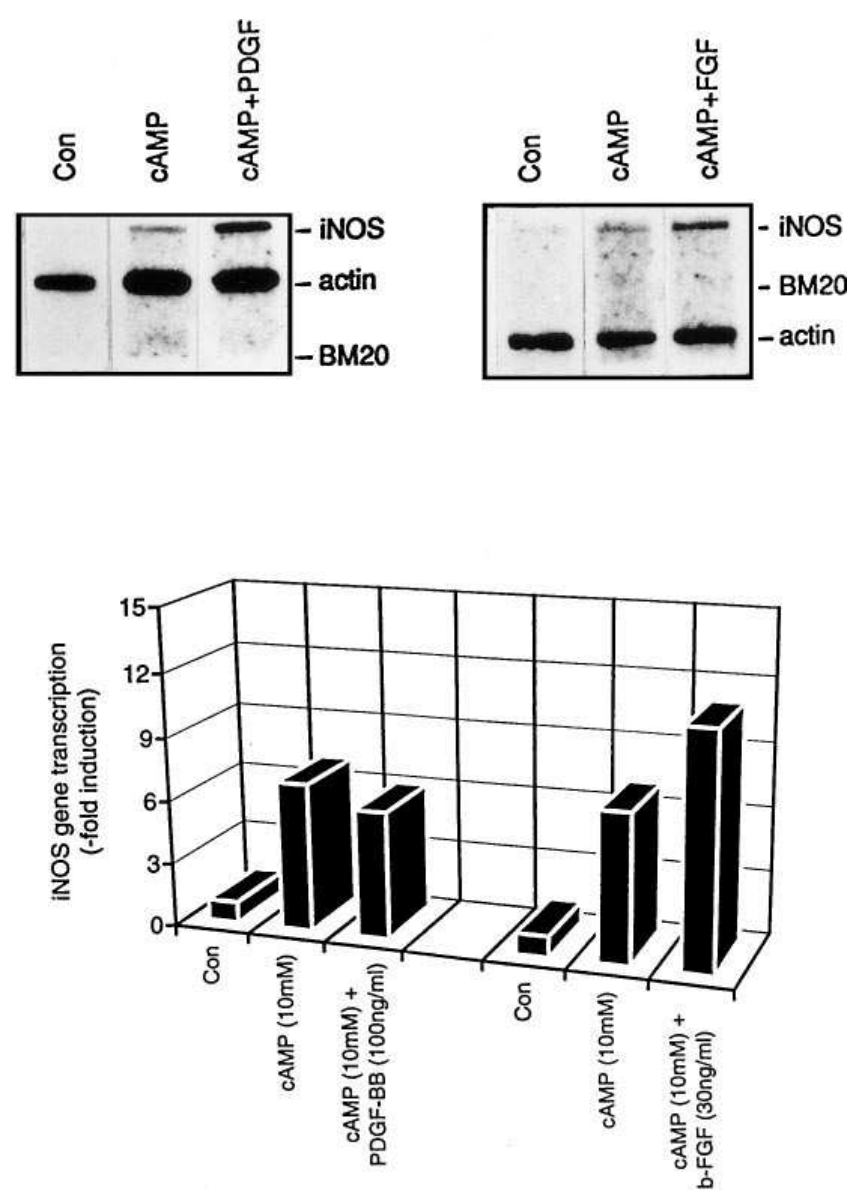

Figure 10. Effects of PDGF-BB and bFGF on cAMP-induced iNOS gene transcription in mesangial cells. Mesangial cells were stimulated for $6 \mathrm{~h}$ with vehicle $(C o n), \mathrm{Bt}_{2} \mathrm{cAMP}(10 \mathrm{mM})$, and $\mathrm{Bt}_{2} \mathrm{cAMP}(10 \mathrm{mM})$ plus PDGF-BB (100 ng/ml) (left), or $\mathrm{Bt}_{2} \mathrm{cAMP}(10 \mathrm{mM})$ plus bFGF $(100 \mathrm{ng} / \mathrm{ml})($ right $)$. The rate of transcription of iNOS and $\beta$-actin genes by isolated nuclei was determined by hybridizing the elongated, ${ }^{32} \mathrm{P}$-labeled RNA transcripts to iNOS cDNA, $\beta$-actin, and pSPTBM20 probes immobilized onto nitrocellulose membranes. To correct for differences in loading, the signal intensity of each sample hybridized to the iNOS probe was divided by that hybridized to the $\beta$-actin probe. The corrected data are displayed as bar graphs in the lower part of the figure. 


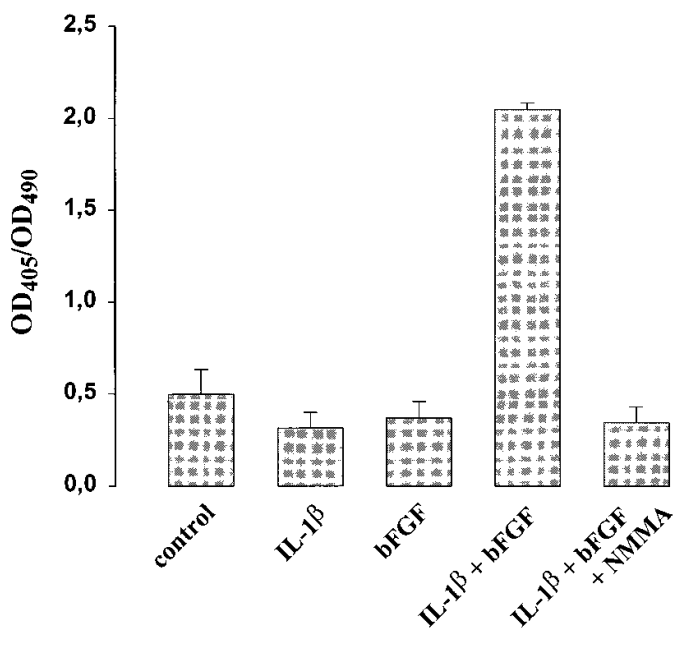

Figure 11. bFGF triggers apoptosis in IL-1 $\beta$-stimulated mesangial cells. Cells were stimulated for $24 \mathrm{~h}$ with vehicle (control); IL-1 $\beta$ $(2 \mathrm{nM}), \mathrm{bFGF}(10 \mathrm{ng} / \mathrm{ml})$ in the presence or absence of L-NMMA $(1 \mathrm{mM})$ as indicated. Thereafter DNA fragmentation was quantified by an ELISA based on the detection of cytosolic histone-DNA complexes. The absorbance ratio $\mathrm{A}_{405 \mathrm{~nm}} / \mathrm{A}_{486 \mathrm{~nm}}$ was measured. Results are means \pm SEM of four independent experiments.

demonstrating an in vivo induction of iNOS in immune complex-mediated glomerulonephritis and indicate that the onset of iNOS gene expression is closely related to the initial deposition of immune complexes. However, these results do not yet allow for the discrimination between mesangial cell or macrophage expression of iNOS in nephritic glomeruli.

Growth factors such as PDGF or bFGF have been shown to be crucially involved in the pathogenesis of many glomerular diseases including rat mesangial proliferative anti-Thy 1.1 glomerulonephritis $(23,51)$. This model is characterized by mesangiolysis, i.e., an acute complement-dependent loss of mesangial cells with disruption of mesangial matrix with a maximum at $24 \mathrm{~h}$ (52). Floege et al. (53) presented evidence that glomerular bFGF is synthesized and released during the mesangiolytic phase. In a second phase, the almost completely eliminated mesangial cell population undergoes rebound proliferation which peaks by $5-10 \mathrm{~d}$ and is accompanied by a marked upregulation of PDGF A and B chain mRNA in total glomerular RNA at 3-5 d after the induction of the disease (52).

There is good evidence that apoptosis of mesangial cells is involved in the early lytic phase in Thy 1.1 glomerulonephritis in vivo (54) and in vitro (55) and thus may account for the rapid mesangiolysis observed during the first $24 \mathrm{~h}$ of the disease. Furthermore, apoptosis is observed in resolving mesangial proliferative nephritis $(56,57)$. The mechanisms underlying mesangial cell apoptosis in early and late phases in Thy 1.1 glomerulonephritis are unknown. In this context it is important to note that in this experimental disease model a significant NO production has been associated with the phase of mesangiolysis (10). Moreover, Narita et al. (12) have shown that blocking NO production in vivo by administration of the NOS inhibitor L-NMMA prevents mesangial cell lysis by $90 \%$, thus suggesting a crucial role for NO in immune-mediated mesangial cell lysis. We have demonstrated recently that NO donors induce apoptosis in glomerular cells including mesangial cells
(42). However, whether endogenously produced NO can fulfil this function critically depends on a balance between reactive nitrogen and oxygen species produced in mesangial cells (43, 44). We assume that the simultaneous generation of $\mathrm{O}_{2}^{-}$relative to NO reflects a protective principle by antagonizing the destructive role of individually active radicals. However, a disturbance of the endogenous $\mathrm{NO} / \mathrm{O}_{2}^{-}$balance by an appropriate increase or decrease of only one radical induces mesangial cell apoptosis (44). In this context, it is most interesting that the bFGF-induced superinduction of NO formation seen in IL-1 $\beta$-stimulated cells is associated with an increased rate of apoptosis of mesangial cells (Fig. 11). Thus, it is conceivable that amplification of iNOS expression and subsequent excessive and unbalanced production of NO crucially contribute to mesangial cell lysis observed in the early phase of Thy 1.1 glomerulonephritis, which is associated with increased bFGF production (53). The subsequent upregulation of PDGF expression may serve to downmodulate NO formation and to trigger reparative mesangial cell growth. Considering our results of differential effects of the growth factors on iNOS expression obtained in mesangial cell cultures, the expression pattern of bFGF and PDGF-BB in the progress of the antiThy 1.1. glomerulonephritis correlates well with the profile of nitrite formation in isolated glomeruli derived from rats suffering from anti-Thy 1.1 glomerulonephritis (10). Additional experimental work will be needed to evaluate this hypothesis.

We and others have shown that two principal classes of activating signals can induce iNOS in mesangial cells. These two groups comprise inflammatory cytokines such as IL-1 $\beta$ or TNF- $\alpha$ (18-20) and agents that elevate cellular levels of cAMP $(21,22)$. Both signal transduction pathways act on the transcription rate of the iNOS gene and subsequently increase iNOS mRNA steady state and protein levels $(21,58)$. Several hormones stimulate adenylate cyclase in mesangial cells, including norepinephrine, histamine, dopamine, calcitonin generelated peptide, and prostaglandins $\mathrm{E}_{2}$ and $\mathrm{I}_{2}$ (13). Whether these hormones modulate iNOS expression in vivo and its possible relevance for glomerular inflammation has yet to be determined. cAMP has also been reported to trigger iNOS expression in vascular smooth muscle cells (59-61), cardiac myocytes (62), and brain microvessel endothelial cells (63).

We now report that PDGF-BB and bFGF differentially affect IL-1 $\beta$ - and cAMP-dependent iNOS expression in mesangial cells, thus extending previous observations on iNOS activity reported by us and others $(33,64)$. The mechanisms underlying these differential actions of PDGF and bFGF are not entirely clear but our results show that coincubation of mesangial cells with PDGF-BB and calphostin C, a potent inhibitor of protein kinase $C$ (39), reverses the inhibitory effect of PDGF. This is important as we have shown recently that the $\epsilon$-isozyme of PKC tonically suppresses iNOS expression in mesangial cells (65) and PDGF activates PKC- $\epsilon$ in mesangial cells (Fig. 4). One possible target for PKC that may mediate inhibition of IL-1 $\beta$-induced iNOS gene transcription is the IL-1 type I receptor. However, the data presented in this report exclude a downmodulation of IL-1 type I receptor mRNA by PDGF-BB (see Fig. 6). By contrast, bFGF strongly potentiates IL-1 $\beta-$ stimulated expression of IL-1 type I receptor mRNA.

Nuclear run-on experiments strongly suggest that the transcriptional machinery involved in the regulation of the iNOS gene is affected by PDGF-BB and bFGF. We have demonstrated that activation of $\mathrm{NF} \kappa \mathrm{B}$ is an absolute requirement for 
IL-1 $\beta$-dependent induction of the iNOS gene in mesangial cells (66). Moreover, members of the CREB and C/EBP transcription factor family seem to play a role in the induction of the iNOS gene by cAMP (Eberhardt, W., and J. Pfeilschifter, unpublished results). The question of whether these transcription factors or the signaling cascades involved in their activation are affected or whether inhibitory factors that suppress iNOS gene transcription are induced by the action of growth factors remains to be investigated. In summary, the data reported in this study provide new insights into the delicate mechanisms of cross-talk between cytokines and growth factors that may be involved in the development of glomerular diseases associated with pathological NO overproduction.

\section{Acknowledgments}

The authors would like to thank Dr. C. Rordorf for kindly providing recombinant human IL-1 $\beta$, Dr. Th. Geiger for the genomic 28 ribosomal RNA clone, and Dr. M. Fox and Dr. M. Pech for the generous gift of $\left(\operatorname{ser}^{70,88}\right)$ bFGF and PDGF-BB, respectively. We gratefully acknowledge Dr. J. Cunningham for providing the pGEM iNOS cDNA clone, Dr. C. Dinarello for the IL-1 type I receptor cDNA clone, and Dr. U. Aebi for the human $\beta$-actin cDNA clone.

This work was supported by Swiss National Science Foundation grant 31-043090.95 and by a grant from the Commission of the European Communities (Biomed 2, PL 950979).

\section{References}

1. Moncada, S., R.M.J. Palmer, and E.A. Higgs. 1991. Nitric oxide: physiology, pathophysiology, and pharmacology. Pharmacol. Rev. 43:119-125.

2. Nathan, C. 1992. Nitric oxide as a secretory product of mammalian cells. FASEB (Fed. Am. Soc. Exp. Biol.) J. 6:3051-3064.

3. Knowles, R.G., and S. Moncada. 1994. Nitric oxide synthase in mammals. Biochem. J. 298:249-258.

4. Nathan, C., and Q.-W. Xie. 1994. Regulation of the biosynthesis of nitric oxide. J. Biol. Chem. 269:13725-13728.

5. Cattell, V., and H.T. Cook. 1993. Nitric oxide: role in the physiology and pathology of the glomerulus. Exp. Nephrol. 1:265-280.

6. Cattell, V., and T. Cook. 1995. The nitric oxide pathway in glomerulonephritis. Curr. Opin. Nephrol. Hypertens. 4:359-364.

7. Cattell, V., T. Cook, and S. Moncada. 1990. Glomeruli synthesize nitrite in experimental nephrotoxic nephritis. Kidney Int. 38:1056-1060.

8. Cattell, V., P. Largen, E. De Heer, and T. Cook. 1991. Glomeruli synthesize nitrite in active Heymann nephritis; the source is infiltrating macrophages. Kidney Int. 40:847-851.

9. Cook, H.T., and R. Sullivan. 1991. Glomerular nitrite synthesis in in situ immune complex glomerulonephritis in the rat. Am. J. Pathol. 139:1047-1052.

10. Cattell, V., E. Lianos, P. Largen, and T. Cook. 1993. Glomerular NO synthase activity in mesangial cell immune injury. Exp. Nephrol. 1:36-40.

11. Weinberg, J.B., D.L. Granger, D.S. Pisetsky, M.F. Seldin, M.A. Misukonis, S.N. Mason, A.M. Pippen, P. Riuz, E.R. Wood, and G.S. Gilkeson. 1994. The role of nitric oxide in the pathogenesis of spontaneous murine autoimmune disease: increased nitric oxide production and nitric oxide synthase expression in MRL-lpr/lpr mice, and reduction of spontaneous glomerulonephritis and arthritis by orally administered $N^{\mathrm{G}}$-monomethyl-L-arginine. J. Exp. Med. 179: 651-660.

12. Narita, I., W.A. Border, M. Ketteler, and N.A. Noble. 1995. Nitric oxide mediates immunologic injury to kidney mesangium in experimental glomerulonephritis. Lab. Invest. 72:17-24.

13. Pfeilschifter, J. 1989. Cross-talk between transmembrane signaling systems: a prerequisite for the delicate regulation of glomerular haemodynamics by mesangial cells. Eur. J. Clin. Invest. 19:347-361.

14. Mené, P., M.S. Simonson, and M.J. Dunn. 1989. Physiology of the mesangial cell. Physiol. Rev. 69:1347-1424.

15. Marsden, P., T.A. Brock, and B.J. Ballermann. 1990. Glomerular endothelial cells respond to calcium-mobilizing agonists with release of EDRF. Am. J. Physiol. 258:F1295-F1303.

16. Pfeilschifter, J. 1994. Mesangial cells orchestrate inflammation in the renal glomerulus. News Physiol. Sci. 9:271-276.

17. Pfeilschifter, J. 1995. Does nitric oxide, an inflammatory mediator of glomerular mesangial cells, have a role in diabetic nephropathy? Kidney Int. 48: S50-S60.
18. Pfeilschifter, J., and H. Schwarzenbach. 1990. Interleukin 1 and tumour necrosis factor stimulate cGMP formation in rat renal mesangial cells. FEBS Lett. 273:185-187.

19. Marsden, P.A., and B.J. Ballermann. 1990. Tumor necrosis factor $\alpha$ activates soluble guanylate cyclase in bovine glomerular mesangial cells via an L-arginine-dependent mechanism. J. Exp. Med. 172:1843-1852.

20. Pfeilschifter, J., P. Rob, A. Mülsch, J. Fandrey, K. Vosbeck, and R. Busse. 1992. Interleukin $1 \beta$ and tumour necrosis factor $\alpha$ induce a macrophagetype of nitric oxide synthase in rat renal mesangial cells. Eur. J. Biochem. 203: 251-255.

21. Kunz, D., H. Mühl, G. Walker, and J. Pfeilschifter. 1994. Two distinct signaling pathways trigger the expression of inducible nitric oxide synthase in rat renal mesangial cells. Proc. Natl. Acad. Sci. USA. 91:5387-5391.

22. Mühl, H., D. Kunz, and J. Pfeilschifter. 1994. Expression of nitric oxide synthase in rat glomerular mesangial cells mediated by cyclic AMP. Br. J. Pharmacol. 112:1-8.

23. Floege, J., E. Eng, B.A. Young, C.E. Alpers, T.B. Barrett, D.F. Bowenpope, and R.J. Johnson. 1993. Infusion of platelet-derived growth factor or basic fibroblast growth factor induces selective glomerular mesangial cell proliferation and matrix accumulation in rats. J. Clin. Invest. 92:2952-2962.

24. Johnson, R.J., J. Floege, W.G. Couser, and C.E. Alpers. 1993. Role of platelet-derived growth factor in glomerular disease. J. Am. Soc. Nephrol. 4: 119-128.

25. Abboud, H.E. 1993. Nephrology forum: growth factors in glomerulonephritis. Kidney Int. 43:252-267.

26. Wardle, N. 1996. Glomerulosclerosis: the final pathway is clarified, but can we deal with the triggers? Nephron. 73:1-7.

27. Green, L.C., D.A. Wagner, J. Glogowski, P.L. Skipper, J.S. Wishnok, and S.R. Tannenbaum. 1982. Analysis of nitrate, nitrite and $\left({ }^{15} \mathrm{~N}\right)$ nitrate in biological fluids. Anal. Biochem. 126:131-138.

28. Bradford, M.M. 1976. A rapid and sensitive method for the quantitation of microgram quantities of protein utilizing the principle of protein-dye binding. Anal. Biochem. 72:248-254.

29. Kunz, D., G. Walker, and J. Pfeilschifter. 1994. Dexamethasone differentially affects interleukin $1 \beta$ - and cAMP-induced nitric oxide synthase expression in rat renal mesangial cells. Biochem. J. 304:3337-3340.

30. Sambrook, J., J. Fritsch, and T. Maniatis. 1989. Molecular Cloning: A Laboratory Manual. Cold Spring Harbor Laboratory Press, Cold Spring Harbor, NY.

31. Huwiler, A., D. Fabbro, and J. Pfeilschifter. 1991. Possible regulatory functions of protein kinase $\mathrm{C}-\alpha$ and $-\epsilon$ isoenzymes in rat renal mesangial cells. Stimulation of prostaglandin synthesis and feedback-inhibition of angiotensin II-stimulated phosphoinositide hydrolysis. Biochem. J. 279:441-445.

32. Huwiler, A., D. Fabbro, S. Stabel, and J. Pfeilschifter. 1992. Immunocharacterization of $\delta$ - and $\zeta$-isoenzymes of protein kinase $C$ in rat renal mesangial cells. FEBS Lett. 300:259-262.

33. Pfeilschifter, J. 1991. Platelet-derived growth factor inhibits cytokine induction of nitric oxide synthase in rat renal mesangial cells. Eur. J. Pharmacol. 208:339-340.

34. Fox, G.M., S.G. Schiffer, M.F. Rohde, L.B. Tsai, A.R. Banks, and T. Arakawa. 1988. Production, biological activity, and structure of recombinant basic fibroblast growth factor and an analog with cysteine replaced by serine. J. Biol. Chem. 263:18452-18458.

35. Pfeilschifter, J., and M. Hosang. 1991. Effects of homo- and heterodimeric isoforms of PDGF on signaling events in rat renal mesangial cells. Cell Signal. 3:413-424.

36. Pfeilschifter, J., and A. Huwiler. 1997. Regulatory functions of protein kinase $\mathrm{C}$ isoenzymes in purinoceptor signaling in mesangial cells. J. Autonom. Pharmacol. 16:315-318.

37. Huwiler, A., E. Schulze-Lohoff, D. Fabbro, and J. Pfeilschifter. 1993. Immunocharacterization of protein kinase $\mathrm{C}$ isoenzymes in rat kidney glomeruli, and cultured glomerular epithelial and mesangial cells. Exp. Nephrol. 1:19-25.

38. Nishizuka, Y. 1995. Protein kinase $C$ and lipid signaling for sustained cellular responses. FASEB (Fed. Am. Soc. Exp. Biol.) J. 9:484-496.

39. Kobayashi, E., H. Nakano, M. Morimoto, and T. Tamaoki. 1989. Calphostin C (UCN-1028C), a novel microbial compound, is a highly potent and specific inhibitor of protein kinase C. Biochem. Biophys. Res. Commun. 159:548-553.

40. Horuk, R., and J.L. Gross. 1990. Protein kinase C-linked inactivation of the interleukin-1 receptor in a human transformed B-cell line. Biochim. Biophys. Acta. 1052:173-178.

41. Aksamit, T.R., M.M. Monick, and G.W. Hunninghake. 1993. Protein kinase $\mathrm{C}$ modulates the amounts of IL-1 receptor mRNA in human lung fibroblasts. J. Immunol. 151:284-290.

42. Mühl, H., K. Sandau, B. Brüne, V.A. Briner, and J. Pfeilschifter. 1996. Nitric oxide donors induce apoptosis in glomerular mesangial cells, epithelial cells and endothelial cells. Eur. J. Pharmacol. 317:137-149.

43. Nitsch, D.D., N. Ghilardi, H. Mühl, C. Nitsch, B. Brüne, and J. Pfeilschifter. 1997. Apoptosis and expression of inducible nitric oxide synthase are mutually exclusive in renal mesangial cells. Am. J. Pathol. 150:889-900.

44. Sandau, K., J. Pfeilschifter, and B. Brüne. 1997. The balance between nitric oxide and superoxide determines apoptotic and necrotic death of rat mes- 
angial cells. J. Immunol. 158:4938-4946.

45. Lüscher, T.F., H.A. Bock, Z. Yang, and D. Diederich. 1991. Endothelium-derived relaxing and contracting factors. Perspectives in nephrology. Kidney Int. 39:575-590.

46. MacAllister, R., and P. Vallance. 1994. Nitric oxide in essential and renal hypertension. J. Am. Soc. Nephrol. 5:1057-1065.

47. Mundel, P., S. Bachmann, M. Bader, A. Fischer, W. Kummer, B. Mayer, and W. Kriz. 1992. Expression of nitric oxide synthase in kidney macula densa cells. Kidney Int. 42:1017-1019.

48. Wilcox, C.S., W.J. Welch, F. Murad, S.S. Gross, G. Taylor, R. Levi, and H.H.H.W. Schmidt. 1992. Nitric oxide synthase in macula densa regulates glomerular capillary pressure. Proc. Natl. Acad. Sci. USA. 89:11993-11997.

49. Jansen, A., T. Cook, M. Taylor, P. Largen, V. Riveros-Moreno, S. Moncada, and V. Cattell. 1994. Induction of nitric oxide synthase in rat immune complex glomerulonephritis. Kidney Int. 45:1215-1219.

50. Cook, H.T., H. Ebrahim, A.S. Jansen, G.R. Foster, P. Largen, and V. Cattell. 1994. Expression of the gene for inducible nitric oxide synthase in experimental glomerulonephritis in the rat. Clin. Exp. Immunol. 97:315-320.

51. Johnson, R.J., E.W. Raines, J. Floege, A. Yoshimura, P. Pritzl, C. Alpers, and R. Ross. 1992. Inhibition of mesangial cell proliferation in glomerulonephritis in the rat by antibody to platelet-derived growth factor. J. Exp. Med. 175:1413-1416.

52. Iida, H., C.E. Alpers, R. Seifert, A. Gown, D. Ross, D. Bowenpope, and R.J. Johnson. 1991. Platelet-derived growth factor (PDGF) and PDGF receptor are induced in mesangial proliferative nephritis in rat. Proc. Natl. Acad. Sci. USA. 88:6560-6565.

53. Floege, J., E. Eng, V. Lindener, A. Young, M.A. Reidy, and R.J. Johnson. 1992. Rat glomerular mesangial cells synthesize basic FGF. Release, upregulated synthesis and mitogenicity in mesangial proliferative glomerulonephritis. J. Clin. Invest. 90:2362-2369.

54. Bagchus, W.M., P.J. Hoedemaeker, J. Rozing, and W.W. Bakker. 1986. Glomerulonephritis induced by monoclonal anti-Thy 1.1. antibodies: a sequential histological and ultrastructural study in the rat. Lab. Invest. 55:680-687.

55. Sato, T., M.G.A. van Dixhoorn, W.E.M. Schroeijers, T.W.J. Huizinga, C.P.M. Reutelingsperger, L.A. van Es, and M.R. Daha. 1996. Apoptosis of cultured rat glomerular mesangial cells induced by IgG2a monoclonal anti-Thy-1 antibodies. Kidney Int. 49:403-412.
56. Baker, A.J., A. Mooney, J. Hughes, D. Lombardi, R.J. Johnson, and J. Savill. 1994. Mesangial cell apoptosis: the major mechanism for resolution of glomerular hypercellularity in experimental mesangial proliferative nephritis. $J$. Clin. Invest. 94:2105-2116.

57. Shimizu, A., H. Kitamura, Y. Masuda, M. Ishizaki, Y. Sugisaki, and N Yamanaka. 1995. Apoptosis in the repair process of experimental proliferative glomerulonephritis. Kidney Int. 47:114-121.

58. Eberhardt, W., D. Kunz, R. Hummel, and J. Pfeilschifter. 1996. Molecular cloning of the rat inducible nitric oxide synthase gene promoter. Biochem. Biophys. Res. Commun. 223:752-756.

59. Koide, M., Y. Kawahara, I. Nakayama, T. Tsuda, and M. Yokoyama 1993. Cyclic AMP-elevating agents induce an inducible type of nitric oxide synthase in cultured vascular smooth muscle cells. J. Biol. Chem. 268:24959-24966.

60. Imai, T., Y. Hirata, K. Kanno, and F. Marumo. 1994. Induction of nitric oxide synthase by cyclic AMP in rat vascular smooth muscle cells. J. Clin. Invest. 93:543-549.

61. Hirokawa, K., K. O'Shaughnessy, K. Moore, P. Ramrakha, and M.R. Wilkins. 1994. Induction of nitric oxide synthase in cultured vascular smooth muscle cells: the role of cyclic AMP. Br. J. Pharmacol. 112:396-402.

62. Oddis, C.Y., R.L. Simmons, B.G. Hattler, and M.S. Finkel. 1995. cAMP enhances inducible nitric oxide synthase mRNA stability in cardiac myocytes. Am J. Physiol. 269:H2044-H2050.

63. Durieu-Trautmann, O., C. Fédérici, C. Crémignon, N. Foignant-Chaverot, F. Roux, M. Claire, A.D. Strosberg, and P.O. Couraud. 1993. Nitric oxide and endothelin secretion by brain microvessel endothelial cells: regulation by cyclic nucleotides. J. Cell. Physiol. 155:104-111.

64. Scott-Burden, T., V.B. Schini, E. Elizondo, D.C. Junquero, and P.M. Vanhoutte. 1992. Platelet-derived growth factor suppresses and fibroblast growth factor enhances cytokine-induced production of nitric oxide by cultured smooth muscle cells. Circ. Res. 71:1088-1100.

65. Mühl, H., and J. Pfeilschifter. 1994. Possible role of protein kinase C-e isoenzyme in inhibition of interleukin $1 \beta$ induction of nitric oxide synthase in rat renal mesangial cells. Biochem. J. 303:607-612.

66. Eberhardt, W., D. Kunz, and J. Pfeilschifter. 1994. Pyrrolidine dithiocarbamate differentially affects interleukin $1 \beta$ - and cAMP-induced nitric oxide synthase expression in rat renal mesangial cells. Biochem. Biophys. Res. Com mun. 200:163-170. 